\title{
Different Cases of SARS-CoV-2 Infection and Its Impact on Health and Economy with Special Emphasis on Antiviral Drug Targets
}

\author{
Hiran Kanti Santra and Debdulal Banerjee* (D)
}

Microbiology and Microbial Biotechnology Laboratory, Department of Botany and Forestry, Vidyasagar University, Midnapore - 721 102, West Bengal, India.

\begin{abstract}
COVID-19 caused by SARS-CoV-2 has not only issued a pandemic situation but also lead to economic disaster and unprecedented health emergency. Being a close relative of Bat corona-virus, SARS and MERS it's structural and sequence similarity has abled scientists for repurposing of popular drugs like hydroxychloroquine, cloroquine and also scavenging for lead molecules by in-silico and in-vivo or in-vitro approach. The potent drug targets are ACE2; spike protein binding receptor to host cell surface, Mpro; proteo-lytic polyprotein processing enzymes needed for virion maturation and RdRp; RNA dependent RNA polymerase needed for RNA replication. The recent trend focuses on the fact that cocktail of anticorona virus treatment will be available soon by broad spectrum antiviral compounds. It takes time to develop such drug targets till then social distancing and following of hygiene are the only way to thrive well. This article incorporates the present World scenario related to COVID infection, focuses on its origin and also future possibilities for a COVID free future.
\end{abstract}

Keywords: ACE2, RdRp, Mpro, COVID-19, in-silico, in-vivo, in-vitro, broad spectrum

*Correspondence: debu33@gmail.com

(Received: April 26, 2020; accepted: April 30, 2020)

Citation: Santra HK, Banerjee D. Different Cases of SARS-CoV-2 Infection and Its Impact on Health and Economy with Special Emphasis on Antiviral Drug Targets. J Pure Appl Microbiol. 2020;14(suppl 1):799-816. doi: 10.22207/JPAM.14.SPL1.17

C The Author(s) 2020. Open Access. This article is distributed under the terms of the Creative Commons Attribution 4.0 International License which permits unrestricted use, sharing, distribution, and reproduction in any medium, provided you give appropriate credit to the original author(s) and the source, provide a link to the Creative Commons license, and indicate if changes were made. 


\section{INTRODUCTION}

Nomenclature, origin and severity

Corona viruses are named so due to their crown like structures. Microscopic and genetic observation of corona viruses looks like they are positive sense, single stranded and protected with pointed structures forming a crown or corona like appearance. They were quiet well known even before the pandemic outbreak of SARS-COV-2 as SARS (Severe acute respiratory syndrome) and MERS (Middle East respiratory syndrome) causing a huge tolls in Earth. Corona viruses first came into scientific knowledge in mid-1960s and was credited to infect humans, animals like birds and mammals ${ }^{1}$. In the year 2003 the first outbreak of corona virus (SARS) occurred on southern China (Guangdong province) and spread to some parts of the globe (other Asian countries, North America, and Europe) but the virus got vanished at the end of 20042,3. MERS was fatal in Saudi Arabia in the year of $2012^{4,5}$.

Cumulatively these two corona virus took 1600 lives. The present situation is also caused by that same group of virus (one type of corona virus out of seven) but this time the severity and infection spreading rate is faster than the previous one. Out of seven corona virus the first four ( $\mathrm{HCoV}$ 229E, HCoV-OC43, HCoV-NL63, HCoVHKU1) are of mild symptoms and do not cause pandemic but the last three (SARSCoV, MERS-CoV, SARS-CoV-2) are highly fatal causing community spreading and severe respiratory disease $e^{6,7}$. These groups of viruses are of common occurrences in animal hosts like vertebrates or mammals but very few of them are known to infect humans. This time a novel strain of corona-virus named as 2019nCoV got detected in a metropolis city Wuhan inhabiting more than 11 million populations in Hubei province, China in the month of December 2019 causing pneumonia like disease ${ }^{8,9}$. The virus was primarily designated as the 2019 novel coronavirus (or 2019- nCoV). The International Committee on Taxonomy of Viruses named the virus as SARS-CoV- $2^{10}$. The World Health Organization (WHO) named the disease caused by the SARS-CoV-2 as Coronavirus disease-2019 or COVID-1911. The viral outbreak first initiated from Wuhan sea-food market of China and got spread all-over the world by international travels, social and community gatherings, school-colleges, pubs etc. leading to massive community spreading according to asynchronous patterns, a typical for any kind of infectious disease as a result of multiple contagious sources. This outbreak is declared as a situation of Public Health Emergency of International concern on January 30 by WHO (World Health Organization) and declared as a pandemic on March 11. In a matter of weeks it spread over 100 countries. Symptoms are general, very common with the pneumonia like, cold, dry cough, headache, sore threat, diarrhea, fever, shortness of breath, aches in muscle, unexplained loss of taste or smell, dyspnea, and fatigue (Fig. 1.). A severe condition may develop viral pneumonia,

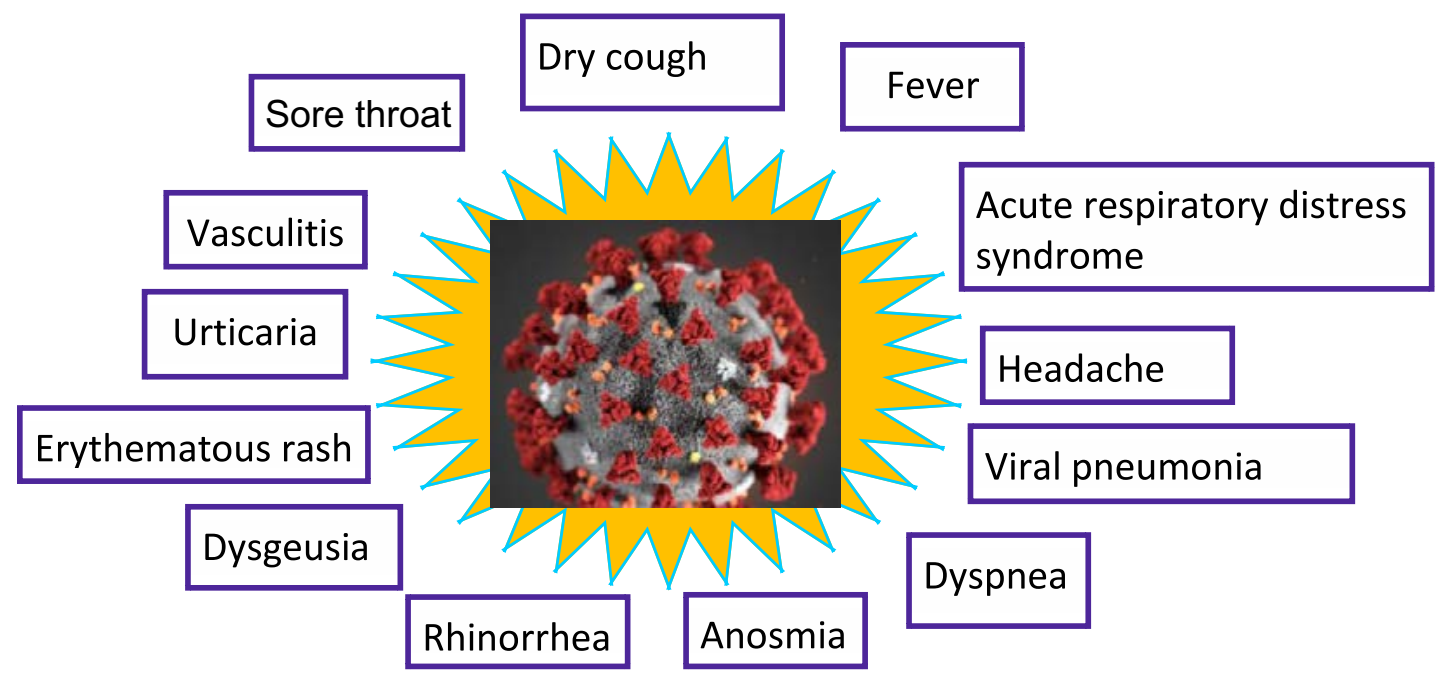

Fig. 1. Different symptoms of COVID-19 infections 
ARD (acute respiratory distress), and hypoxia, needing intubation and mechanical ventilation ${ }^{12}$. The possible infection methods include droplet transmission, when an infected person sneezes or coughs the viral particles are released through aerosols into air and may remain on the surface for over a day and can infect a healthy host. Generally the droplet travels less than a few feet and fall onto the ground and any persons coming into contact with that surface may got infected.

The one and only measures for prevention of getting infected by corona virus includes physical and social distancing and maintaining proper hygienic protocols like frequently washing of hands with soaps for 20 seconds or by alcohol based sanitizers, avoid coming in close contact with persons having cough or sneeze or have an immediate national or international travel history from infected zones, cover ones mouth while coughing, sneezing or cough into flexed elbow to avoid the release of aerosols onto the air etc. (Fig. 2.). Few cases include severe respiratory syndrome and kidney failure. The immune-compromised patients or patient those have high blood sugar, diabetes, hypertension, cancer, chronic respiratory disease and cardiovascular disease are tense to get infected easily by this disease (WHO). It is very important to be aware of the myths that young aged people are free from any kind of risk. It is to be kept in mind that maximum percentage of people doesn't have a natural immunity against this infection. For that reason it will take time of month or year to develop proper medications or measures to eliminate it from the population but until then social distancing and lockdown are known to be the best possible measures. Not only School, Colleges, University or markets are offline but also health care systems for treatments other than COVID cases are running in high risk or in case of emergency. In case of liver transplantation the patients are prior immunocompromised thus a donor to recipient or donor to health care staffs and vice versa transmission of virus may occur. This infection depends upon donors' exposure to viral particles, incubation period, viral viability in blood, sera or specific organs and degree of viremia ${ }^{13}$. Thus some regulations are implemented for this type of major organ transplant cases for both donor and recipient. Both of them should be COVID negative with no symptoms of disease and devoid of any recent International travel history. The rules are equally effective for both DDLT (deceased donor liver transplant) and LDLT (living donor liver transplant) patients to maintain a safe transplantation ${ }^{14}$. This deadly virus is closely related to a group of SARS-like coronavirus under

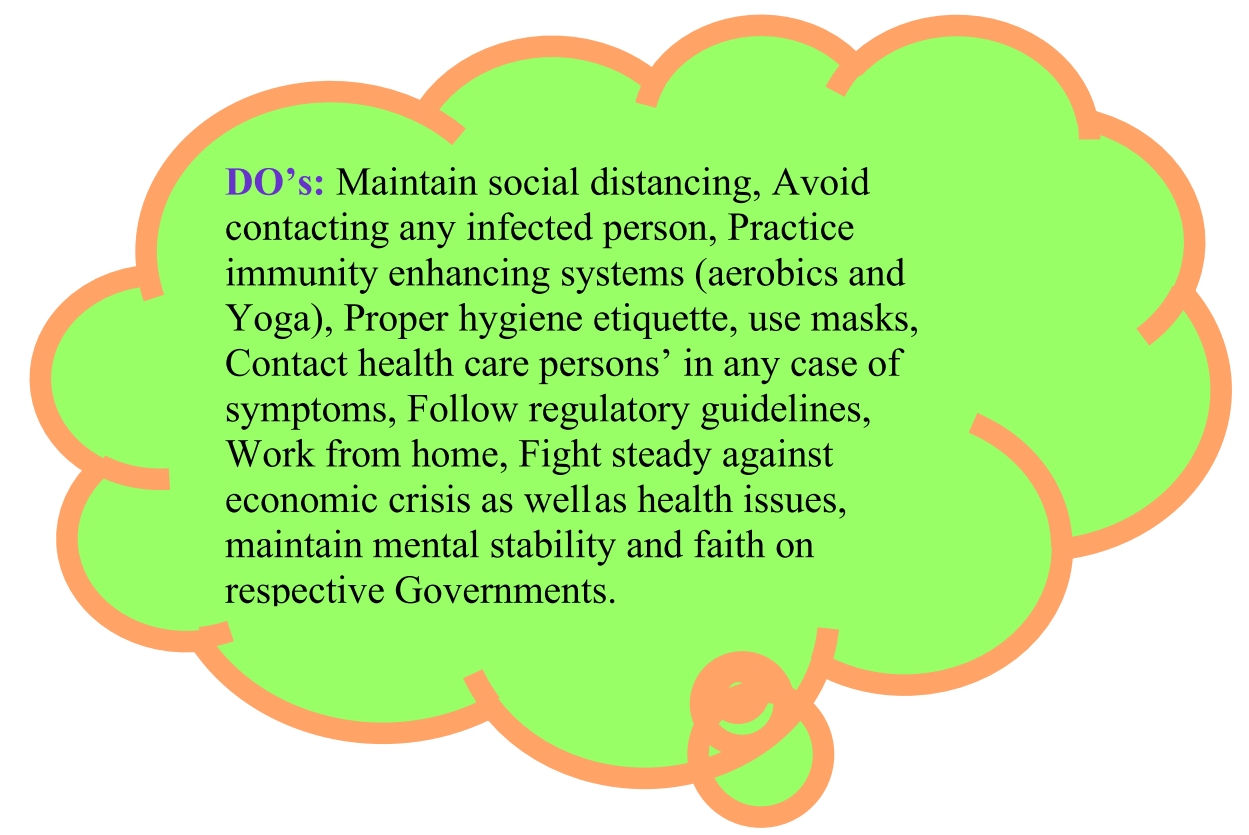

Fig. 2. Possible measures should be taken by any World citizen to be safe in the days of COVID risks 
the genus Betacoronavirus and of the sub-genus Sarbecovirus which was actually a virus found to be infecting bats in China ${ }^{15}$. This 29,903 nucleotide containing virus with $81 \%$ similarity with animal virus is a proof that virus from animal to human transfer occurs (Zoonotic). Data derived from public and published ones helps in estimating the overall symptomatic case severity of COVID-19 in particularly the city of Wuhan was noted to be $1.4 \%$ which was much lower than both the crude or native confirmed case fatality risk (4.5\%), the ratio of deaths and death plus recoveries was $11 \%$ on $29^{\text {th }}$ February, 2020. In a comparison to age group of 30 to 59, the persons aged below 30 and above 59 were more prone to infection $(0.6 \%$ and $5.1 \%$ respectively) and death by COVID. The risk of symptomatic infection gets increased according to age like, $4 \%$ per year in case of adults aged 30 to 60 years $^{16}$. Corona virus spread happened in a bullet speed covering the whole Hubei province and also major parts of the mainland China and also across the Globe (199 countries) with in a time of 30 to 60 days mainly due to international travelling and community spreading. Actually the cases are found to be asymptomatic in some situations also making it more badly. A report upto February 11, 2020 includes that a total number of 72,314 patients were diagnosed for COVID-19 and $61.8 \%$ of them are found to be confirmed positive candidates. The rest $22.4 \%$ are of suspected cases and $14.6 \%$ are clinically diagnosed one also $1.2 \%$ is of asymptomatic type. The most of the confirmed case represents an age group of 30-
79. The author made this observation based on the factors like summary of patient characters, age distribution and sex ratio, case fatality and mortality rates, geo temporal analytical data, analysis of infected or susceptible subgroups and construction of epidemiological curve ${ }^{17}$. Recent reports have provided the information on body site specific viral replication, immunity and infectivity. The researchers examined nine cases where satisfactory proofs were found regarding the active viral replication in case of upper respiratory tract tissues. Pharyngeal viral shedding was of high amount for the first week of symptoms appearance and viral RNA was isolated from throat-lung swab samples but not from stool, blood and urine samples.

Occurrence of viral replicative RNA intermediates in throat samples and occurrence of sequence distinct viral populations on both throat and lung samples were the proof of independent viral replication (Fig. 3.). Viral RNA was also found in sputum, samples ${ }^{18}$. Air borne infections in case of COVID-19 is still not reported. Reports which include air borne occurrence of aerosols with virus are generally the cases where any aerosol generating situation has been created either artificially (generation of aerosol by a three-jet Collison nebulizer and provided to Goldberg drum) or normally during the time of treatment providing to patients ${ }^{19}$. The artificial experiment reports occurrence of aerosols on closed system for three hours though the power of that aerosol generator was much higher than normal human cough

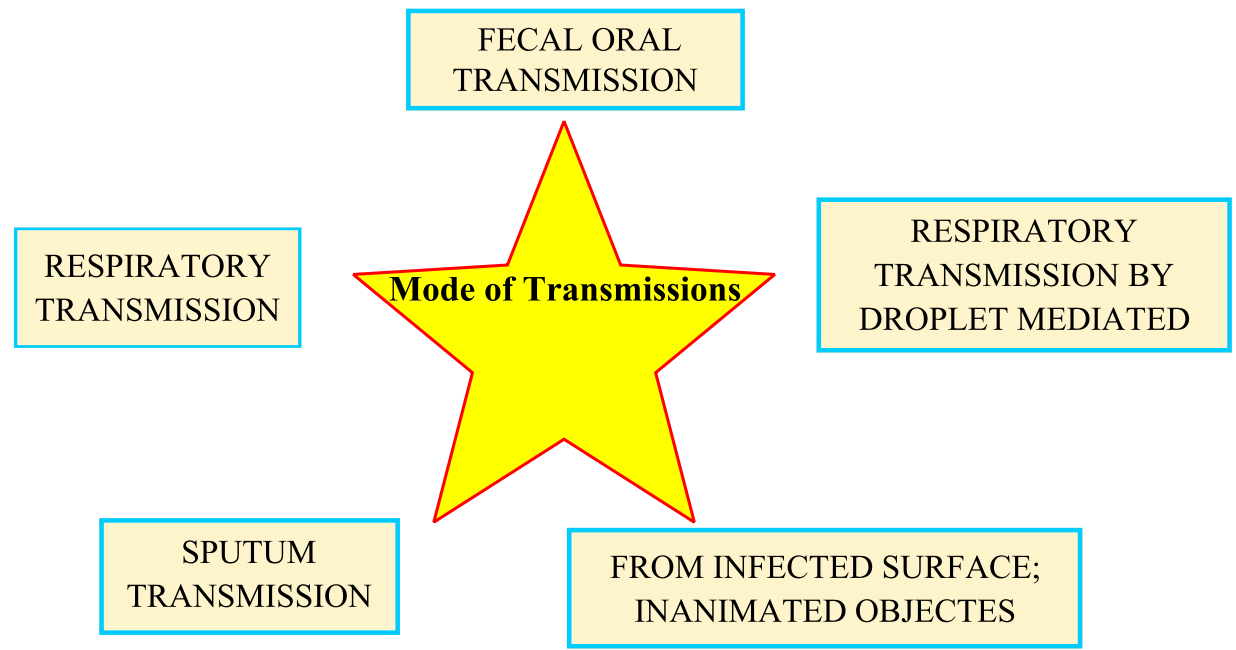

Fig. 3. Possible mode of transmissions of COVID-19 by patient to patient; community transmission 
speed. In hospital conditions where COVID positive patients were admitted occurrence of viral RNA was noticed ${ }^{20,21}$. But it is also a fact that occurrence of aerosol always does not mean that it contains viable transmissible virus particles. What-ever it is care must be taken from any kind of infection chance especially for the health care personnel who generally deals with lots of viral loads $s^{22,23}$. And it is high-time that everyone must follow the national and international guidelines ${ }^{24-27}$. Every-one should follow the respiratory etiquette, physical distancing, hygiene maintenance and proper precautions with complete sincerity to cope up with this situation ${ }^{28}$.

Mode of transmissions

To infect a viable potent susceptible host the cellular entry of the viral particles both the glycoprotein and genetic RNA is mandatory in case of COVID (beta-coronavirus) infections. So for cross species transmission cellular entry is the first and foremost criteria. Cell entry is an essential component of cross-species transmission, where the surface glycoprotein spike actually binds to the host cell receptor and facilitates viral entry ${ }^{29}$. In this case, a single particular constant region of the spike protein known as receptor binding domain (RBD) performs the host cell receptor interaction. Just after the binding to the receptor, a protease enzyme of host cell cleaves the spike and mediates the release of spike fusion peptide facilitating the virus entry ${ }^{30-31}$. So, the host receptors play a major role here like ACE-2 (Angiotensin-converting enzyme 2) and DPP4 (Dipeptidyl peptidase-4) for SARS-CoV-2 and MERS-CoV respectively ${ }^{32-33}$. As COVID-19 cause respiratory infections the possible mode of transmissions are nothing but the droplets of varying sizes. The size of droplets may vary i.e. $>5-10 \mu \mathrm{m}$ in diameter; called as respiratory droplets or $<5 \mu \mathrm{m}$ in diameter; known as droplet nuclei ${ }^{34}$. It is obvious that COVID-19 is primarily transmitted through respiratory droplets and contact routes ${ }^{35-40}$. Droplet transmission is mediated by contact closure of within 1 meter of range of any diseased persons causing infection into healthy people through mucosae of nasal or oral path and conjunctiva (eyes). Other than this type of direct infection indirect infection routes are also fatal which includes contaminated stethoscopes, thermometers, hospital wastes or PPEs (Personal protective equipment) etc. The most vital indirect mode of transmission includes in-animated objects used by the infected person in the immediate environment surrounding that person ${ }^{21}$. The highest risk occurs through air borne infection which includes occurrence of viable microbes in the form of droplet nuclei that can survive in air for a prolonged time and may travel over 1meter causing severe infections. Chances of air borne transmission are only restricted to handling of infected person through medical devices that may induce aerosol formation like bronchoscopy, tracheostomy, cardiopulmonary resuscitation, manual ventilation, endotracheal intubation, nebulized treatment, non-invasive ventilation etc. Recent research emphasizes on the fact that COVID-19 can lead to intestinal infection and may be present in huge amount in fecal material of the infected person that enhances the risk of any person getting infected through the flush based generated aerosols ${ }^{41}$. But lack of evidence on fecal-oral transmission needs further scientific attention. A recent pediatric study on ten individuals include that patients were free from any kind of symptoms like, none of the children required respiratory support system and there was no sign of pneumonia like disease even in chest X-Ray. But out of ten; eight children were found to be positive for COVID infection when tested by real time reverse transcriptase PCR from rectal swab but was negative when tested from nasopharyngeal swab raising questions about the possibility of fecal-oral transmission ${ }^{42}$.

Obesity increases susceptibility for COVID infections

Diabetes and obesity in adults or young aged peoples causes them more susceptible to COVID ${ }^{43,44}$. The relationship between obesity and respiratory disease is quiet clear. Excess weight may lead to asthmatic situations, obstructive sleep apnea syndrome, acute lung injury, adult respiratory distress syndrome. High BMI i.e. overweight situation leads to accumulation of adipose tissue under the skin that induce secretion of IL-6 (interleukein-6), a common medical situation found in all SARS-CoV-2 nonsurvivors ${ }^{45}$. Eculizumab and Tocilizumab that act as a compliment system modulator and receptor inhibitor respectively acts as a solution and trials are on for this purpose in countries like USA and Italy (ClinicalTrials.gov Identifier: NCT04288713). 
Obesity is characterized by low grade systemic inflammation making the obese patients more prone to get infected ${ }^{46,47}$. Obese patients develop cytokine storm as a result of compliment system activation leading to inflammatory situations ${ }^{48}$. Recent studies on mice model opens up the discussions that mice with $\mathrm{C3}$ deficient type when infected with adequate viral load responds better in terms of respiratory function compared to wild type one as a result of reduced IL- 6 secretion in both lung and sera ${ }^{49}$. It has been obtained from the researches that fat droplets got accumulated in the alveolar interstitial and lung parenchyma of infected objects like rats ${ }^{50}$ causing inflammatory infiltrate ${ }^{51}$. This deadly virus uses an Angiotensinconverting enzyme 2 (ACE-2) based entries to host cells. These receptors are also expressed by fat or adipose tissues including ectopic reservoirs ${ }^{52}$. Though the scientific data regarding the adipose tissue tropism of COVID-19 is not clear, but this virus may get an easy proliferation in patients with obesity, hypertension, diabetes, age related complications causing chronic inflammation, increased activation of compliment system and over accumulation of IL-6. The exact link between obesity and COVID-19 infection may throw some light on the fact that obese COVID-19 infected people can be cured by administering medicines that modulate IL- 6 action or compliment system. Other than that these type of information is helpful for health care professionals to diagnose the risk of an obese person getting infected higher than the non-obese one ${ }^{53}$.

Issues with TCZ

Though a robust large sample sized data on monitoring parameter, pharmacotherapy, and diagnostic considerations of population is needed for proper establishment of humanizied antibody tocilizumab (an interleukin-6 receptor antibody) as a potent weapon against this disease but TCZ is progressing as a viable and effective treatment option in severe COVID-19 patients ${ }^{54}$. Risk with random use of tocilizumab is related to development of hypertriglyceridemia in patients treated with this medicine ${ }^{55}$. A case study includes the information that COVID-19 patients with ARDS (severe acute respiratory distress syndrome), AP (acute pancreatitis) having elevated IL-6 (interleukein-6), lactate dehydrogenase (LDH), d-dimer, ferritin (inflammatory markers) receives
TCZ treatment along with lopinavir/ritonavir, ribavirin, hydroxychloroquine, propofol as sedative and triglyceride levels increase. It was obvious that TCZ is the reason of hyper-triglyecridimea as IL- 6 act as an immunomodulator and metabolism controller. An IL-6 elevation mobilizes free fatty acid through adipocytes and provides stimulation to skeletal muscles for glucose and free fatty acid uptake from the serum ${ }^{56,57}$. Inhibition of membrane bound and soluble IL-6 receptor due to TCZ treatment interferes with the above said metabolic pathway and increase TGA levels. So, special care should be taken in case of patients with chronic TCZ use, infected with COVID-19 and going to be treated with TCZ. Patients infected with COVID-19 are known to be of high IL-6 levels ${ }^{58,59}$. Surgical face masks as a common protecting measure

A recent study includes primarily screening of 3363 people and finally enrolling 246 of them to volunteer. $50 \%$ of them wore mask and the rest were devoid of mask. A documentation of viral load on their exhaled breath was made for three viruses; influenza, rhino, corona and samples from nasal and throat swabs, respiratory droplet and aerosol were analyzed for viral shedding. The common symptoms of patients infected with COVID-19 were high fever $\left(\geq 37.8^{\circ} \mathrm{C}\right)$ and coughed mostly during the 30 minutes viral shedding study. It has been found that viral shedding was highest in nasal swabs followed by throat swab. Viral RNA for NL63 human corona virus was detected from aerosol samples only using RT-PCR as the tool. It has been also found that people wearing mask did not contain any viral RNA. So to be free from the risk of corona virus infection the best measures are to use surgical masks, N-95 or any kind of two or three layered mask. Health authorities also recommended to have masked based protection first to the persons with flu or cough, i.e. to prevent onward transmission by control of the source ${ }^{60,61}$ then to common asymptomatic people. Other than this common hand hygiene are needed to be maintained for safety ${ }^{62}$.

Issues with SOT (Solid organ transplant)

Organ transplanted patients are generally known to be immunocompromised possessing a higher threat to get infected by SARS-CoV-2 infection. Here is a case study that reveals that a 39 year aged patient with multi organ transplant 
(heart/kidney) history on 2017 due to idiopathic dilated cardiomyopathy and CKD (chronic kidney disease) when detected as COVID positive from nasopharyngeal swab survives the situation instead of several complications like obesity, moderate blood sugar or $\mathrm{HbA} 1 \mathrm{C}$ of $10.5 \%$. Other than the common symptoms of COVID-19 like high fever of $101.8^{\circ} \mathrm{F}$, headache, sore throat, dry cough, dyspnea, fatigue, and myalgia the patient was found to be with poorly maintained IDDM (insulin-dependent diabetes mellitus), hypertension, morbid obesity (body mass index (BMI) of $38.4 \mathrm{~kg} / \mathrm{m}^{2}$ ), and chronic diabetic foot ulcers. As a result his laboratory test results were not good like low WBC (white blood cell) count of $2.4 \times 10^{3} / \mathrm{uL}$, lymphopenia- $0.23 \times 10^{3} / \mathrm{UL}$, CRP (C-reactive protein) levels were elevated- 6.7 $\mathrm{mg} / \mathrm{dL}$, serum lactate- $27 \mathrm{mg} / \mathrm{dL}$, LDH (lactate dehydrogenase)- $361 \mathrm{U} / \mathrm{L}$, procalcitonin value was $<0.1 \mathrm{ug} / \mathrm{mL}$, mildly elevated troponin $1-0.17 \mathrm{ng} / \mathrm{mL}$ with normal BNP (B-type natriuretic peptide)- 43 $\mathrm{ug} / \mathrm{mL}$, elevated $D$-dimer of $1124 \mathrm{ng} / \mathrm{mL}$. This type of finding shades a ray of hope for patients with organ transplant in the days of COVID infections ${ }^{63}$. Labor issues and economic crisis

COVID has hit hard on the backbone of the World economy. The situation is so dangerous that lock down of all the sectors except the most needed one is the only way to minimize the rapid community spreading of this disease. But this situation has made the economic crisis more badly and have directly affected on sectors like food, agriculture, industry, pharmaceutical, car manufacturing etc. The labors are the worst affected individuals in this time. A complete shutdown has forced them to move from their work place and they have only option to return to their nest with bare hands. The situation in upcoming weeks will be beyond our imagination if lock down persists. As a result normalcy of the situation is highly needed to restore the balance between demand and supply ratio avoiding a disaster on essential economic and business sectors. Statistics of US and Canada has emphasized the fact that after the lock down period will over and once the ban will be withdrawn there would be a supreme hike on labor (also TFWs-temporary foreign workers) leading to loss on business sectors and some industries may got so lame that they might never reopen. The situations are severe in urban sectors than rural areas as rural economy is autotrophic in nature and needs less currency to survive offering very cheaper way to thrive the unpleasant situation where as urban life is highly demanding starting from arranging food to vegetable and paying bills to EMls. Whatever, this tough time needs smart and efficient futuristic managers to cope up with situation. To maintain the proper GDP and NPP over shifting by small amount of workers or involvement of quality time and good quantity of labor will be the possible remedies. As the solid structures will remain as it is, because this situation is not something that may devastate like storm or flood efficient handling of situation will regain the previous normalcy in a quick manner. The recovery rate may vary from one country to another and in present Globalized situation the slower recovering underdeveloped countries will act as rate determining enzyme and slow down the progress of faster recovering countries ${ }^{64}$.

Asymptomatic carrier based transmission of COVID; probably the worst scenario

COVID infected patients are known to have visual macro type symptoms that could have been diagnosed easily and proper action taken at time may avoid further spread of infections. Case study of China throws some light on the negative side of the fact that asymptomatic carriers may cause disease in healthy human beings and spread the pandemic in a silent way. A family of 5 had the infection transmitted from a member of 20 year old lady who had travel history from Wuhan infection site to Anyang, China. Though that 20 years old asymptomatic carrier had not immediately developed any kind of symptoms (high fever, gastrointestinal or respiratory symptoms) within the long incubation range of 0 to 24 days ${ }^{65}$ but even her RT-PCR (Real time reverse transcriptase polymeric chain reaction) detection of viral RNA was negative for the first time that might be a complex of several failure factors like poor quality of kit, inefficient sample handling and wrong test procedure. Though the chances of a false negative results due to mishandling in these highly alarming situation is a rare chance of occurrence but researchers still emphasize that ${ }^{66}$ and her results were positive for the second time on January 28 and again was negative on February 5 and 8 . The situation is 
more threatening as all of his hematological and biochemical parameters like C-reactive protein, $\mathrm{mg} / \mathrm{L}$, Eosinophils, $\times 10^{9} / \mathrm{L}$, Eosinophil ratios, \% Lymphocytes, $\times 10^{9} /$ L Lymphocyte ratios, $\%$ 20-50 Neutrophils, $\times 10^{9} / \mathrm{L}$ Neutrophil ratios, $\%$ 40-75 White blood cell count, $\times 10^{9} / \mathrm{L}$ were within normal reference range showing no indications of disease occurrence but the members without any source of secondary infection other than that 20 year old girl family member had all these parameters with abnormal values supporting the other findings in a huge number of patients. Other than increased $\mathrm{C}$ reactive proteins and decreased lymphocyte count all the infected patients have "multifocal groundglass opacities on chest CT, and sub-segmental areas of consolidation and fibrosis. Another case of a 10 year old boy being asymptomatic in most of the tested parameters but had abnormal CT values but in this 20 year old female candidate even the CT reports were normal ${ }^{67}$. If this situation replicates or persists or became a common trend of disease occurrence it will not only be impossible to detect viral infection but also would create an unmanageable situation ${ }^{68}$.

Cutaneous manifestations; new symptoms of COVID infections

Other than the common symptoms like, anosmia (Loss of test), rhinorrhea (Congestion on the nasal chamber due to runny nose), diarrhoea (loose motion) and dysgeusia (altered taste), erythematous rash (redness of skin either in a limited area or whole portions of the skin), widespread urticaria (irritating rash) and chicken-pox like vesicles were also reported. The characteristics of cutaneous manifestations like place i.e. where they appeared (face and upper body), when they appeared i.e. during pro-dermal, illness or during decline period including its symptoms like itching or burning were analyzed by the dermatologists or consulting doctors in Italy ${ }^{69}$. They also reported the occurrence of Herpes Simplex infections like lesions. Rashes were accompanied with itching and they disappeared within 2 to 6 days. Small blood vessel occlusion leads to development of livedoid eruption (https:// www.the-hospitalist.org/hospitalist). Other than that purplish or red maculopapular, vesiculous lesions were found on hand and feet digits with pain and chill burn sensations. Skin biopsy of some patients refers to vasculitis that is probably due to COVID infections. Failure in conventional systems has brought more facts during the days of COVID like, High Flow Nasal Cannula (HFNC) is known to be a common measure of ventilation for corona virus infected patients but patients with lower $\mathrm{PaO}_{2}$ and $\mathrm{FiO}_{2}$ are not going to be treated successfully by this method ${ }^{70}$.

Structural relationship of SARS CoV-2 with previous corona virus

It has been known that binding of corona virus to ACE2 receptor is the critical step for COVID infection. That binding accelerates a cascade of one by one event that finally leads to the fusion of cell membrane and viral cell membrane and facilitates entry to host cell leading to invasion ${ }^{71}$. It induces S1 and ACE2 dissociation prompting the S2 to transit from a metastable pre-fusion to a more stable post-fusion state which is essential for membrane fusion ${ }^{72-75}$. Hela cells that express ACE2 receptor is found to be susceptible to COVID infection but those who don't have these functional receptor are not infected ${ }^{76-78}$. The binding affinity of the SARS-CoV-2 RBD (receptor binding domain) and ACE2 occurs in low $\mathrm{nm}$ range emphasizing the fact that RBD is the major functional unit of S1 subunit mainly responsible for SARS-CoV-2 binding ${ }^{79}$. Presently the cryoelectron microscopic data reveals a lot about the virus physical structure (spike trimer) but the modeling of RBM (Receptor binding motif) that interacts with ACE-2 is still scanty ${ }^{80,81}$. The cross-neutralizing reactivity of serum or plasma antibody was found but till now no monoclonal antibodies have been isolated that can effectively bind to RBD and neutralize SARS-CoV-2 infections. It has been found from the recent studies that there are some intrinsic differences regarding structure and sequence between the RBD's of SARS CoV and SARS-CoV-2. X-ray crystallography was used as a tool to elucidate the complex structure between SARS-CoV-2 RBD and ACE2 receptor with a better resolution. The atomic level structures are necessary for development of vaccine designs which are of urgent need for winning the present combat with corona virus. Scientist expressed SARS-CoV-2 RBD (residue of Arg319-Phe541) along with $\mathrm{N}$-terminal peptidase domain of ACE2 (residues of Ser19-Asp615) in HI5 insect cells. Purification was done by Ni-NTA affinity and gel filtration and finally by molecular replacement 
the complex structure was determined (refined at $2.45 \AA$ resolutions). Finally that model contains residues of Thr333-Gly526 of the SARS-CoV-2 RBD, Ser19-Asp615 of ACE2 N-terminal peptidase domain, one zinc ion, four NAG glycans linked to ACE2, Asn90, Asn322 and Asn546 for RBD Asn343 with 80 water molecules. Phylogenetic analysis of corona virus genomes focuses on the fact that it is a new member of beta coronavirus genus that en-calculates other corona viruses like SARS-CoV, MERS-CoV, bat SARS corona virus etc. ${ }^{9,82,83}$. It has been revealed that bat corona-virus RaTG13 is known to be the closest relative of the SARSCoV-2 with a similarity percentage of $93.1 \%$ of spike genes. That type of structural similarity and in-silico similarity creates an argue over the statement of convergent evolution of SARS CoV-2 and SARS-CoV RBD's for better binding to ACE2. Potent combating agents; the hope for a COVID free future

On April 4, 2020 the probable number of assured infected persons on earth is actually $1,139,207^{84}$. So it is high time to go for the remedies to stop this global pandemic (Fig. 4.). Drugs are being tested by the scientists in a rapid speed to cope up this situation. Nafamostat is a synthetic serine protease inhibitor that can inhibit the growth of MERS CoV. Other than that Nitazoxanide being an antiprotozoal agent shows antiviral activity against respiratory viral groups like influenza, para-influenza, respiratory syncytial virus and also rhino virus. Recent invitro studies indicate that these two agents can reduce SARS-CoV-2 infection ${ }^{85}$. As development of new drugs to combat any kinds of disease is time taking, costly and at these high time immediate solutions are needed so drug repurposing is the key way of research to combat COVID infections. Like reuse of chloroquine, hydroxychloroquine, azithromycin, ACE2 inhibitor etc. Cell based phenotypic assay is useful but at this time it will not be able to elucidate on molecular target and will not be compatible with high throughput sequencing ${ }^{86,87}$. So in-silico testing is the time saving and efficient way to find quick answers. Mpro is known as a prime COVID enzyme that maintains viral replication and transcription ${ }^{88,89}$. So any drug that can stop this enzyme will be the miraculous one ${ }^{90}$. Data from crystal structure and molecular docking has proved that drugs can bind to the substrate binding pocket of COVID-19 Mpro which is highly conserved in all corona viruses and may save persons' from infection. Scientists have screened a mechanism based inhibitor N3 by insilico method and they have used high throughput sequencing to check anti COVID activity of 10,000 known drugs (some are clinically approved and some are on clinical trials for approval). Six of them were screened to have potent IC50 values of 0.67 $21.4 \mu \mathrm{M}$. COVID-19 genome is constructed with 30,000 nucleotides and the replicase gene codes for two overlapping polyproteins named as pp1a, pp1ab which are most important for viral central dogma ${ }^{9,83}$. These polyproteins undergo digestion by a Main protease (known as Mpro-33.8 kDa/ $3 \mathrm{C}$ like protease) into 11 conserved sites initiated by the autolytic cleavage of this enzyme itself from pp1a, pp1ab ${ }^{91}$. Ebselen (organoselenium

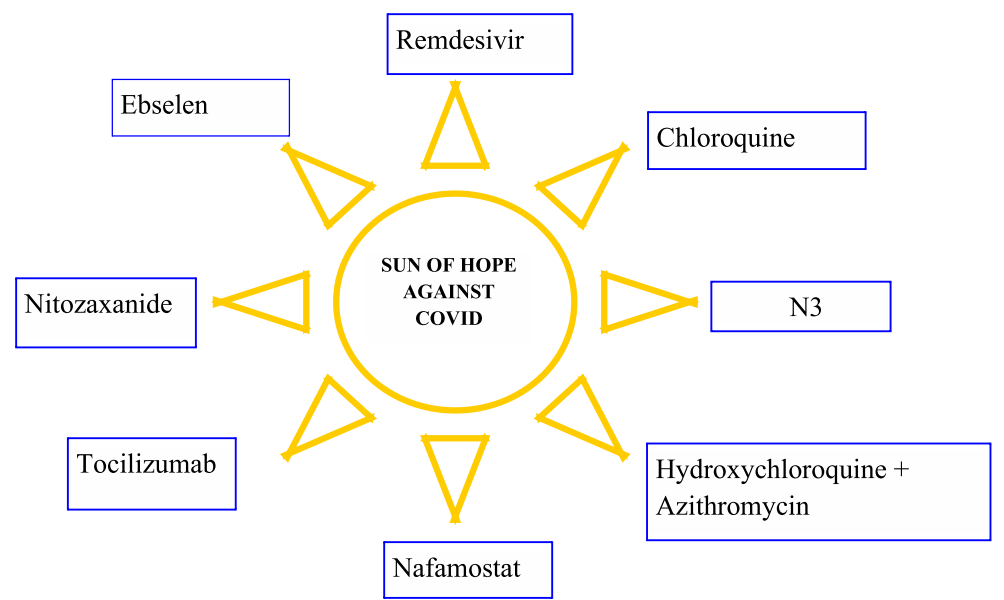

Fig. 4. The probable potent agents to restrict the SARS-CoV-2 Tsunami 
compound) is popular for its anti-oxidative, cryoprotective and anti-inflammatory ability and other than that this was known to show anti COVID activity (tested against COVID infected vero cell line as Mpro inhibitor) at a $10 \mu \mathrm{M}$ concentration and EC50 value of $4.67 \mu \mathrm{M}$ (Fig. 5.). It has minimum amount of toxicity and used in control of disease like bipolar disorder and hearing loss ${ }^{92-96}$.Other than that N3 and cinanserin displayed anti COVID activity with EC50 value of $16.77 \mu \mathrm{M}$ and $20.61 \mu \mathrm{M}$ (confirmed by qRT-PCR). Research suggests that both the Ebelsen and N3 were able to penetrate cellular membrane to access their cellular targets. Cinanserin might have multidrug targets to prevent viral infection but further studies are needed for confirmation. RBD (receptor binding domain) of COVID-19 is similar to SARS corona virus and both of them utilize ACE-2 for cellular entry 9 . ACE2 (a carboxy-peptidase that converts angiotensin II to angiotensin 1-7) acts as a negative regulator of the RAS (Renin angiotensin system) and is actually a homolog of ACE and its expression is specifically found in heart, kidney, epithelial cells to avoid vasoconstriction effect of angiotensin II 97,98. Medicines that can interact with these ACE or ARBs in case of COVID patients can show positive response to fight with this disease ${ }^{99}$. Remdesiver, an antiviral drug interferes with the RDRP (RNA dependent RNA polymerase) named as nsp12 of COVID-19 which is involved in replication and transcription of the viral genetic content. The recent cryo electron microscopic structure of the COVID-19 virus illustrates the full length $n s p 12$ in a complex with its cofactors nsp7 and nsp8 at a resolution of $2.9 \AA$. Other than the normal structure of the polymerase, nsp12 contains a new $\beta$-hairpin domain at its $\mathrm{N}$ terminus. This structure of the viral RdRp finally opens up new horizons for the development of new therapeutics ${ }^{100}$.

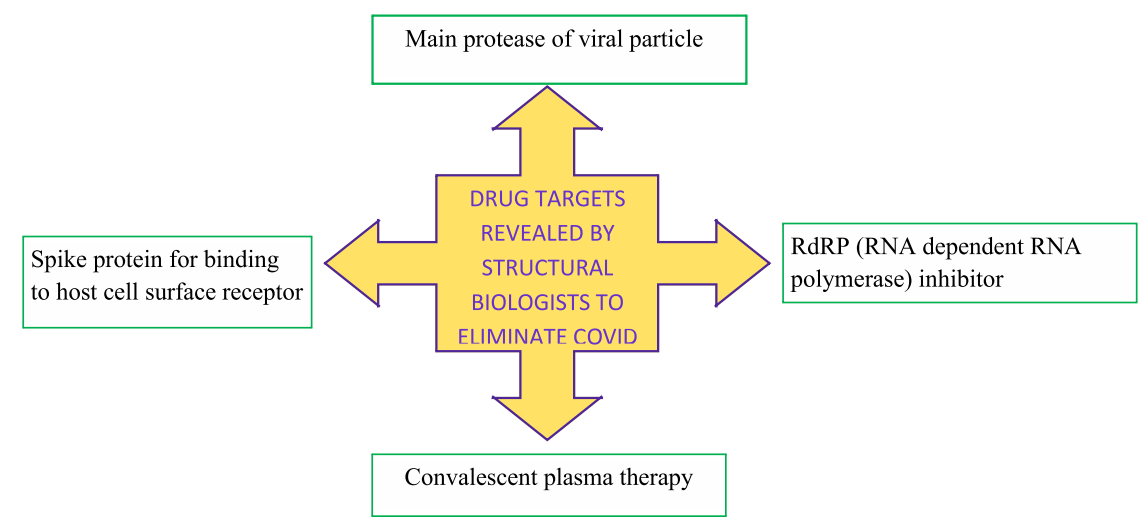

Fig. 5. Different drug targets to stop SARS-CoV-2 infection

Common FDA (Food and Drug Administration, USA) approved antiviral drugs like; ribavirin, penciclovir, nitazoxanide, nafamostat, chloroquine, Remdesiver (GS-5734) and favipiravir (T-705) were tested in-vitro against COVID infections. Chloroquine being a cheap and economically feasible drug with a long safe usage history of 70 years is a potent anti-malarial and autoimmune disease drug with broad spectrum antiviral activity with potent anti COVID activity ${ }^{70,101}$. It actually interfere glycosylation of cellular receptors of SARS CoV and also cause increase of endosomal $\mathrm{pH}$ that may hamper viral and cellular fusion thus blocks viral infection ${ }^{102}$. Chloroquine is known to function at both entries and post-entry status of Vero E6 cells (infected with 2019-nCoV) with an EC90 value of $6.90 \mu \mathrm{M}$ (after $500 \mathrm{mg}$ oral administration) which is similar with the value of rheumatoid arthritis patient treated with this drug ${ }^{103}$. Being an immune enhancing medicine it also increase the antiviral activity and it has been found to be cosmopolitan in distribution in whole body. Other than chloroquine also hydroxychloroquine coupled with azithromycin is proved to be reducing the viral load in nasal swab of French patients and finally disappearance of COVID symptoms may open up boom of opportunities to survive against this disease ${ }^{104}$. Anti-malarial drugs also used as anti-rheumatic drug alters lysosomal proteases that may block viral entry to host cell ${ }^{105}$. So, in 


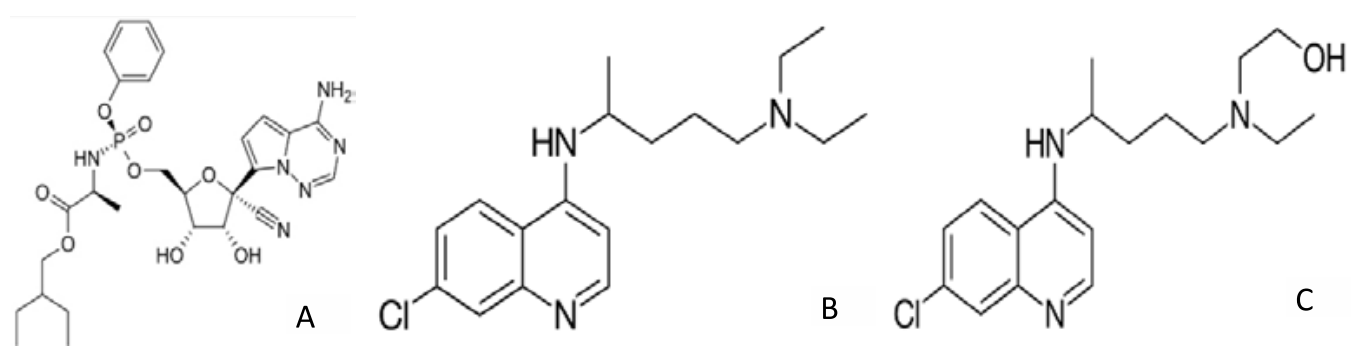

Fig. 6. Structure of potent anti-viral agents to combat COVID infection; A- Remdesivir; B- Chloroquine; CHydroxychloroquine

a word compounds like remdesivir, cloroquine, hydroxycloroquine etc. are still engaging hopes for human kind (Fig. 6.).

Neutralizing antibodies

Antibodies formed in an individual's body as a sign of resistance against viral infection is technically named as neutralizing antibodies. Reports include that SARS-CoV-2 could be crossneutralized by anti-SARS-CoV serum derived from horse and convalescent serum treatment from SARS infected patient ${ }^{9,78}$. As, there are structural similarity between SARS-CoV-2 and SARS-CoV RBDs (Receptor binding domain) so, there are signs of hope that monoclonal antibodies will be applied rapidly to control the disease. But the fact is that till now not even a single antibody of SARS-CoV (m396, S230, 80R and CR3014) has been able to provide a satisfactory result in cross reaction and neutralization against SARS-CoV-2 spike or RBD ${ }^{76}$, ${ }^{106}$. Antibody CR3022 that acts against SARS-CoV binds to SARS-CoV-2 RBD having a KD of $6.2 \mathrm{~nm}$ but its neutralizing ability is not confirmed still ${ }^{79}$, ${ }^{80}$. Presently it is not clearly known that exactly at which position the epitope of CR3022 binds on SARS-CoV and SARS-CoV-2. The two antibodies (m96 and 80R) that were not found suitable to bind to the RBD of SARS-CoV-2 were analyzed for their epitopes (Fab-RBD complex) high resolution crystal structures ${ }^{107,108}$. When the epitope mapping sequences were aligned for SARS-CoV RBD and SARS-CoV-2 RBD, it had been found that antibody m396 has a change of 7 residue in the SARS-CoV2-RBD among 21 epitope positions and in case of $80 \mathrm{R}$ monoclonal antibody there was a 16 residue change among 25 epitope position. These are the in-silico protein data base record that clarify that why $\mathrm{m} 396$ and $80 \mathrm{R}$ lacks cross reactivity. The spike protein regions represent conserved non-RBD portions like S2 subunit that is actually the prime target for cross reactive antibodies. In-spite of the fact that RBD is less conserved, similar residues were found to be present between SARS-CoV-2 and SARS-CoV RBD also in the most variable RBM (receptor binding motifs) cases. As RBD is the most important region for receptor binding reactions, monoclonal antibodies targeting the conserved epitope in the receptor binding domain provide a ray of hope for the development of most potent cross reactive therapeutic agents to combat this situation.

\section{Managing tough ICU issues}

In these days of COVID handling ICU situations for the SARS-CoV-2 infected patients have been a serious issue. Doctors and nurses or medical staffs from all over the World face issues with infection and lack of proper guidance and it looks like the normal recommendations are not always full-proof to handle this situation is a right way. So, proper guidance is of utmost importance. To meet the need scientists, researchers and medical professionals from all over the globe have set some strict recommendations over five potent issues; (1) infection control, (2) laboratory diagnosis and specimens, (3) hemodynamic support, (4) ventilatory support, and (5) COVID-19 therapy. The panel of 36 experts covering 12 countries has given 54 statements of which 4 are known to be the "best practice statements", 9 are "strong recommendations" and 35 are "weak recommendations"109. Some of those recommendations are listed in table 1 categorically (Table 1).

Effect on Indian economy

COVID-19 has caused a lockdown of 40 days in the subcontinent of India. The business sector along with the non-Govt. private sector people is to face the adverse situation in a more harsh manner. Govt. has allowed ration to the 
Table 1. Some weak and strong recommendations on handling of diseased ICU patients; given, supported, and followed by leading authorities and disease control agencies around the Globe.

\begin{tabular}{|c|c|c|}
\hline $\begin{array}{l}\text { Sl. } \\
\text { No. }\end{array}$ & Recommendations & \\
\hline 1 & $\begin{array}{l}\text { Use of PPEs (Personal protective equipment) like; N95 respirators, FFP2, } \\
\text { gloves, gown, and eye protection, such as a face shield or safety goggles. }\end{array}$ & \\
\hline 2 & $\begin{array}{l}\text { Endotracheal intubation in serious patients to be done by the most experienced } \\
\text { one to complete in a single attempt reducing the risk of contamination. }\end{array}$ & $\begin{array}{l}\text { For infection } \\
\text { control and } \\
\text { testing purpose }\end{array}$ \\
\hline 3 & $\begin{array}{l}\text { Performing aerosol generation system in case of ICU (Intensive care unit) } \\
\text { patients in a negative pressure room. }\end{array}$ & \\
\hline 4 & $\begin{array}{l}\text { In case of adults suffering from COVID-19 and shock dopamine (advised to } \\
\text { use norepinephrine) and hydroxyethyl starch (for acute resuscitation) are not } \\
\text { recommended }\end{array}$ & $\begin{array}{l}\text { For } \\
\text { hemodynamics }\end{array}$ \\
\hline 5 & $\begin{array}{l}\text { Recommendations are there to maintain high } \mathrm{SpO} 2 \text { not higher than } 96 \% \text { in } \\
\text { case of COVID-19 patients with acute hypoxemic respiratory failure on } \\
\text { oxygen }\end{array}$ & \\
\hline 6 & $\begin{array}{l}\text { COVID Patients treated with NIPPV/ HFNC required strict monitoring and } \\
\text { early intubation to control the situation }\end{array}$ & \\
\hline 7 & $\begin{array}{l}\text { Low tidal volume of ventilation with } 4-8 \mathrm{~mL} / \mathrm{kg} \text { of body weight in case of } \\
\text { COVID infected adults are recommended }\end{array}$ & For ventilation \\
\hline 8 & $\begin{array}{l}\text { Plateau pressures should be }<30 \mathrm{~cm} \mathrm{H} 2 \mathrm{O} \text {; in case of COVID infected patients } \\
\text { with ARDS }\end{array}$ & \\
\hline 9 & $\begin{array}{l}\text { In case of mechanically ventilated adult COVID patients a higher PEEP is } \\
\text { recommended (barotrauma should be checked). }\end{array}$ & \\
\hline 10 & A staircase recruitment maneuvers are not recommended. & \\
\hline
\end{tabular}

common people to avoid food crisis. People are facing job issues and sectors like transport, hotel and restaurants, light and heavy manufacturing, utilities, construction, business, trade and personal services, public sectors, agriculture, mining and quarrying are going to face tough equations. In a country of over $1,210,193,422$ people (according to 2010-2011 census data) it is tough to maintain a lockdown situation and also provide all the necessary basic needs to the poor and needy people. But Indian Government has tried their best to serve bread and butter to the countrymen and in a recent Nation-wise address of honorable Prime Minister Narendra Damodar Modi, he has designated each countrymen as a soldier playing their part to stop the COVID pandemic. Indian economy might face GDP issues as import and export services are not running smoothly. In case of worst hypothetical scenario India is going to face GDP loss of \$29917 million and more than 10 lakh unemployments (according to the Asian Development bank's prediction). India is dependent on China regarding the purpose of raw materials import and presently supply from China is discontinuous as a result input prices may rise and profit may reduce sharply leading to a decline in capacity building.

A decline in Global and domestic demand may occur because sudden unemployment reduces consumer spending, export demands to the top destinations like China, USA, and Europe declines, low investment by the common man, fall of share price, restriction on movement and fear of falling sick etc. Banking sector to face problems as stock market declines, sharp fall of rupee against the dollar etc. Falling oil prices could be marginal positive impact on Indian economy but rupee depreciation may minimize the gain. Indian industrial sectors like textile, apparels (US\$64million) and chemicals (US\$129million) are to be worst affected due to slow down of Chinese production units. A $2 \%$ slowdown on Chinese production can affect US\$350 million in Indian industries like communication equipment, electrical machinery, leather products, machinery, metals and metal products, office machinery, paper products and publishing, precision instruments, rubbers and plastics, wood products and furniture etc. Following the Oxford's global economic model a probabilistic economic outlook could be given. 
There are three possible scenario that how this crisis could be handled in India. The first one is the optimistic scenario with a $V$ shaped curve of recovery; here it could be expected that the contagion is controlled by June 2020 by effective Government strategies. Then economy will regain rapidly. In $2^{\text {nd }}$ case optimistic approach along with severity and a $U$ shaped recovery. Here the supply-chain problem may rise rapidly and India may have very poor control on the disease spread issues leading to taking a lot of time to be back to normalcy. The third one is really a pessimistic one with drastic effect on the continent's situation. In this severe situation the disease spreads vulnerably impacting decline in demands and slowing down productions. From this situation a slow modest recovery is expected and in a time span of 2 years the economy grows 1.5-2 percent lower than the expected graph. Recovery is expected to be unequal in this case. Segmental impact on pharmaceuticals and power industry are thought to be remain less in a comparison to gems and jewelry, textiles, automobile components, consumer durables and electronics etc. The worst cases may be seen in case of airlines, hotels, malls, multiplexes, poultry, retailers and restaurants etc. A quick recovery is to be expected in food and beverage industry as frozen and instant food supply needs be fast during the time of pandemic, stocking of essential food components is a common measure taken during lockdown shows greater demand initially thus the liquidity of the demand and production should not collapse this industry.

Once the situation revives consumers demand towards safety and security, food handling and processing, packaging is likely to increase. So, that will cause a change in patterns of production and maintenance of food components. Apparel, footwear and beauty sectors are to face very low demand. Regarding automobile sector as it is largely dependent on China for raw material import it may face problems and problems will be higher in case of two wheeler sector than four or fifth wheeler ones. The demand of buses, passenger vehicles and commercial vehicles are likely to decrease. India may change strategy on their import and start importing from Germany, South Korea, Japan, Thailand until Chinese manufacturing lines normalize. But there is a chance of low supply as the alternate routes may lead to price hike. Due to COVID pandemic the global auto industry and consumption is likely to be affected largely leading to export issues for component manufacturers. In India this may hit hard on economy. Consumer market response should be critically analyzed for a safe secure and smart assured business strategy. The situation has impacted a broad change on the mind setup of common man. After recovering from the crisis people will go for necessities and will emphasize on value for money or justified purchase or well managed lifestyle and economic plan with a moderate shopping list. So company should also change their policies to meet the need offering a wide range of products in low cost in an efficient manner. So there should be no gap between customers' need and companies brand based marketing policy and quality assurance. The void of Chinese supply may motivate Indian companies to look over their strategies and convert to manufacturing hubs or production units rather than depending on import options. Online market is to be more popular as it means social distancing and reduces work pressure for consumers. The business sectors need to focus the following for a successful recovery; ensure health and safety of one and all, have a good cash-flow management, communicate proactively with all types of consumers, shift from offline to online (e-commerce), speeding up non-urban consumption, social media marketing campaigns, classify stock availability, ensure vivid social responsibility, offer few touch point delivery to carry customers' peace of mind and enhance cashless transactions. Govt. of India has provided monetary stimulus to maintain the spending power of consumers toward necessary commodities.

Various State Governments along with central Govt. and NGO's have organized relief packages, common people are providing mass funding, film-stars, and leading industrialists are raising their hands of support to maintain a normal flow of economy. Govt. authorities are providing capital support, reconstructing loans, supporting consumers, webbing charges to relief the situation. More-over RBI (Reserve Bank of India) has cut its repo rate by 75 basis points (here 100 basis points=1percent) to offer 
a sigh of relief on the countrymen. A cut on GST (Goods and sales tax) on particular sectors like health, essential commodities, sanitation, foods etc. may enhance the situation in a much better way. Indian economy in a successful participation of Government, active help of common people and efficient strategy of businessmen are hoped to rise in a fantastic way. (The statistical data are extracted from reports generated by Deloitte analysis on COVID-19 situations on India and from Government announcements.)

\section{CONCLUSION}

In a situation of Global pandemic due to sudden outbreak of a deadly virus having no strong solution against it, is a situation that the World has not faced in recent times. In each and every case our science and technology sectors have send some rescues but this time still the search is on to minimize the severity of disease. It is just a matter of time that today's Giant killer will defeat and human race will conquer again but till then to support our Government, health care system, researchers we must follow the general rules and recommendations to protect our family members and loved ones from falling sick. Recent study has warned us that in this home stuck conditions mental issues like depression, anxiety, over eating, heart problems, metabolic disorders like hyper tension, blood sugar due to lack of physical or mental activity may distress you but we have to maintain our daily routine in a serious way efficiently to avoid any kind of extra health burden on Health care facilities in this serious times 110. We have to remember that healthy lifestyle behaviors with proper diet, physical exercise is the key force to survive against all kind of infection or metabolic issues ${ }^{111}$. As drugs clinical trials are on pipeline till then proper maintenance of NPIs (nonpharmacological interventions) like self-isolation, physical distancing are the prime weapon to fight this situation (Fig. 7).

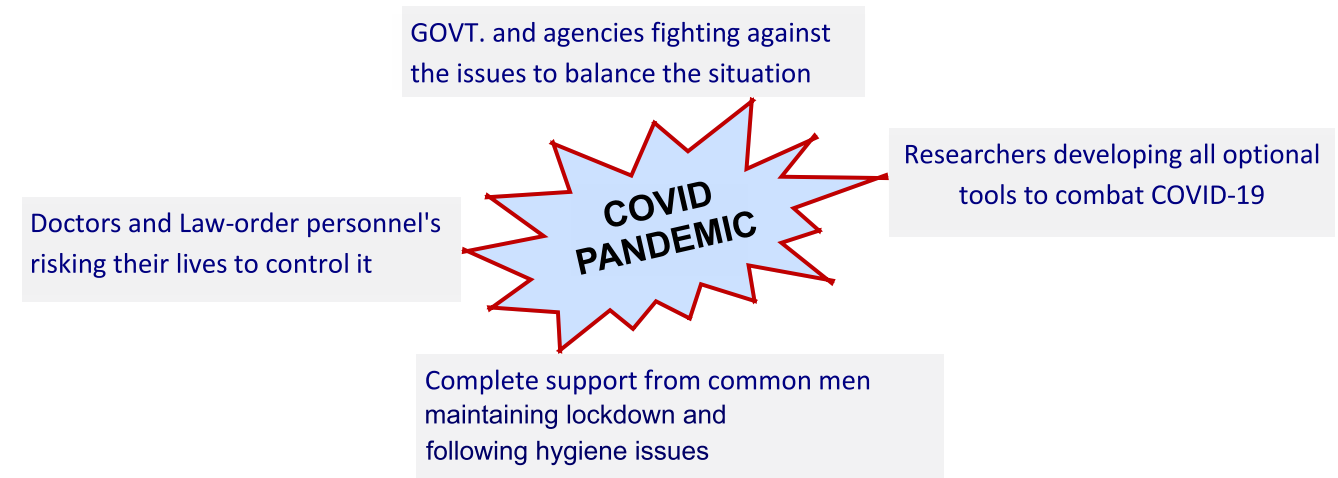

Fig. 7. The best key factors presently fighting to save the World from COVID infections

\section{ACKNOWLEDGMENTS}

Authors are thankful to the Vidyasagar University for necessary support.

\section{CONFLICT OF INTEREST}

The listed author(s) declare no conflict of interest in any capacity, including competing or financial.

\section{AUTHORS' CONTRIBUTION}

All listed author(s) have made a substantial, direct and intellectual contribution to the work, and approved it for publication.

\section{FUNDING}

None.

\section{ETHICS STATEMENT}

This article does not contain any studies with human participants or animals performed by any of the authors.

\section{AVAILABILITY OF DATA}

Not applicable.

\section{REFERENCES}

1. Kahn JS, Mclntosh K. History and Recent Advances in Coronavirus Discovery. Pediatr Infect Dis J. 2005;24:223-227. 
2. Peiris JS, Guan Y, Yuen KY. Severe acute respiratory syndrome. Nat Med. 2004;10:S88- 97.

3. Pyrc K, Berkhout B, van der Hoek L. Identification of new human coronaviruses. Expert Rev Anti Infect Ther. 2007;5:245-253.

4. Memish ZA, Zumla Al, Al-Hakeem RF, AlRabeeah AA, Stephens GM. Family cluster of Middle East respiratory syndrome coronavirus infections. N Engl J Med. 2013;368:2487- 2494

5. Rahman A, Sarkar A. Risk Factors for Fatal Middle East Respiratory Syndrome Coronavirus Infections in Saudi Arabia: Analysis of the WHO Line List, 2013-2018. Am J Public Health. 2019;109:1288- 1293.

6. Cui J,Li F, Shi ZL. Origin and evolution of pathogenic coronaviruses. Nat Rev Microbiol. 2019;17:181-192.

7. Zumla A, Hui DS, Perlman S. Middle East respiratory syndrome. Lancet. 2015;386:995-1007.

8. Wu F, Zhao $S$, Yu B, et al. A new coronavirus associated with human respiratory disease in China. Nature. 2020;579:265-269.

9. Zhou P, Yang XL, Wang XG, et al. A pneumonia outbreak associated with a new coronavirus of probable bat origin. Nature. 2020;579:270-273.

10. Wu Y, Ho W, Huang Y, Jin DY, Li S, Liu SL, Liu X, Qiu J, Sang Y, Wang Q, Yuen KY. 2020. SARS-CoV-2 is an appropriate name for the new coronavirus. The Lancet. 2020;395(10228):949-950.

11. Coronavirus disease COVID pandemic, 2020: situation summary. Accessed: March 20, 2020: https:// www.cdc.gov/coronaviru/2019-ncov/casesupdates/ summary.html

12. Huang $C$, Wang $Y, L i X$, et al. Clinical features of patients infected with 2019 novel coronavirus in Wuhan, China. Lancet. 2020;395:497-506.

13. Michaels MG, La Hoz RM, Danziger-Isakov L, et al. Coronavirus disease 2019: Implications of emerging infections for transplantation. Am J of Transplant. 2020;00:1-5.

14. Saigal S, Gupta S, Sudhindran S, et al. Liver transplantation and COVID-19 (Coronavirus) infection: guidelines of the liver transplant Society of India (LTSI). Hepatol International. 2020;1.

15. Wu F, Zhao S, Yu B, et al. 2020. A new coronavirus associated with human respiratory disease in China. Nature. 2020;579(7798):265-269.

16. Wu JT, Kathy L, Mary B, et al. Estimating clinical severity of COVID-19 from the transmission dynamics in Wuhan, China. Nature Medicine. 2020;1-5.

17. The epidemiological characteristics of an outbreak of 2019 novel coronavirus diseases (COVID-19) in China. Zhonghua liu xing bing xue za zhi Zhonghua liuxingbingxue zazhi. 2010;41(2):145.

18. Wolfel R, Corman VM, Guggemos W, et al. Virological assessment of hospitalized patients with COVID-2019. Nature. 2020;1-10.

19. Van Doremalen N, Bushmaker T, Morris DH, et al. Aerosol and surface stability of SARS-CoV-2 as compared with SARS-CoV-1. New Engl J of Med. 2020.

20. Cheng VC, Wong SC, Chen JH, et al. Escalating infection control response to the rapidly evolving epidemiology of the Coronavirus disease 2019 (COVID-19) due to SARS-CoV-2 in Hong Kong. Inf Con \& Hosl Epidemio,
2020;1-6.

21. Ong SWX, Tan YK, Chia PY, Lee TH, Ng OT, Wong MSY, Marimuthu K. 2020. Air, surface environmental, and personal protective equipment contamination by severe acute respiratory syndrome coronavirus 2 (SARS-CoV-2) from a symptomatic patient. JAMA. 2020;1-3.

22. Interim Infection Prevention and Control Recommendations for Patients with Suspected or Confirmed Coronavirus Disease 2019 (COVID-19) in Healthcare Settings. https://www.cdc.gov/ coronavirus/2019-ncov/infection-control/controlrecommendations.html

23. Infection prevention and control for COVID-19 in healthcare settings. https://www.ecdc.europa.eu/en/ publications-data/infection-prevention-and-controlcovid-19-healthcare-settings

24. Surviving Sepsis Campaign: Guidelines on the Management of Critically III Adults with Coronavirus Disease 2019 (COVID-19). Intensive Care Medicine DOI: 10.1007/s00134-020-06022-5 https://www.sccm. org/SurvivingSepsisCampaign/Guidelines/COVID-19

25. Interim guidelines for the clinical management of COVID-19 in adults Australasian Society for Infectious Diseases Limited (ASID) https://www.asid.net.au/ documents/item/1873

26. Coronavirus disease (COVID-19): For health professionals. https://www.canada.ca/en/publichealth/services/diseases/2019-novel-coronavirusinfection/health-professionals.html

27. Guidance on infection prevention and control for COVID-19 https://www.gov.uk/government/ publications/wuhan-novel-coronavirus-infectionprevention-and-control

28. Ran L, Chen X, Wang Y, Wu W, Zhang L, Tan X. Risk factors of healthcare workers with corona virus disease 2019: A retrospective cohort study in a designated hospital of Wuhan in China. Clinical Infectious Diseases. 2020; doi/10.1093/cid/ciaa287/5808788.

29. Li F. Structure, function, and evolution of coronavirus spike proteins. Annu Rev Virol. 2016;3:237-261.

30. Simmons G, Zmora P, Gierer S, Heurich A, Pohlmann S. Proteolytic activation of the SARS-coronavirus spike protein: cutting enzymes at the cutting edge of antiviral research. Antiviral Res. 2013;100:605-614.

31. Letko M, Andrea M, Vincent M. Functional assessment of cell entry and receptor usage for SARS-CoV-2 and other lineage $B$ betacoronaviruses. Nature Microbiology. 2020;5(4):562-569.

32. Raj VS, Mou H, Smits SL, et al. Dipeptidyl peptidase 4 is a functional receptor for the emerging human coronavirus-EMC. Nature. 2013;495(7440):251-254.

33. Li W, Moore MJ, Vasilieva N, Sui J, et al. Angiotensinconverting enzyme 2 is a functional receptor for the SARS coronavirus. Nature. 2003;426(6965):450-454.

34. World Health Organization. Infection prevention and control of epidemic- and pandemic-prone acute respiratory infections in health care. Geneva: World Health Organization; 2014 Available from:https://apps.who.int/iris/bitstream/ handle/10665/112656/9789241507134_eng. pdf?sequence $=1$ 
35. Liu J, Liao X, Qian S, Yuan J, et al. Community Transmission of Severe Acute Respiratory Syndrome Coronavirus 2, Shenzhen, China. Emerging Infectious Diseases. 2020;26(6).

36. Chan JFW, Yuan S, Kok KH, et al. A familial cluster of pneumonia associated with the 2019 novel coronavirus indicating person-to-person transmission: a study of a family cluster. The Lancet. 2020;395(10223):514-523.

37. Li Q, Guan X, Wu P, et al. Early transmission dynamics in Wuhan, China, of novel coronavirus-infected pneumonia. N Engl J Med. 2020;382(13):1199-1208.

38. Huang C, Wang Y, Li X, et al. Clinical features of patients infected with 2019 novel coronavirus in Wuhan, China. Lancet. 2020;395(10223):497-506.

39. Burke RM, Midgley CM, Dratch A, et al. Active monitoring of persons exposed to patients with confirmed COVID-19 - United States, January-February. MMWR Morb Mortal Wkly Rep. 2020;69(9):245-246.

40. World Health Organization. Report of the WHO-China Joint Mission on Coronavirus Disease 2019 (COVID-19) 16-24 February 2020 [Internet]. Geneva: World Health Organization; 2020

41. Zhang Y, Chen C, Zhu S, et al. Isolation of 2019-nCoV from a stool specimen of a laboratory-confirmed case of the coronavirus disease 2019 (COVID-19 China CDC Weekly. 2020;2(8):123-4.

42. Xu Y, Li X, Zhu B, et al. Characteristics of pediatric SARSCoV-2 infection and potential evidence for persistent fecal viral shedding. Nature medicine. 2020;1-4.

43. Maddaloni E, Buzzetti R. Covid-19 and diabetes mellitus: unveiling the interaction of two pandemics. Diabetes Metab Res Rev. 2020:33213321.

44. Guo W, Li M, Dong Y, et al. Diabetes is a risk factor for the progression and prognosis of COVID-19. Diabetes Metab Res Rev. 2020;3319.

45. Zhou F, Yu T, Du R, et al. Clinical course and risk factors for mortality of adult inpatients with COVID-19 in Wuhan, China: a retrospective cohort study. Lancet. 2020;395(10229):1054-62.

46. Reilly SM, Saltiel AR. Adapting to obesity with adipose tissue inflammation. Nat Rev Endocrinol. 2017;13(11):633-43.

47. Mancuso P. Obesity and lung inflammation. J Appl Physiol. 2010;108(3):722-8.

48. Karkhaneh M, Qorbani M, Mohajeri-Tehrani MR, Hoseini S. Association of serum complements C3 with metabolic syndrome components in normal weight obese women. J Diabetes Metab Disord. 2017;16:49.

49. Gralinski LE, Sheahan TP, Morrison TE, et al. Complement Activation Contributes to Severe Acute Respiratory Syndrome Coronavirus Pathogenesis. mBio. 2018;9(5).

50. Foster DJ, Ravikumar P, Bellotto DJ, Unger RH, Hsia CC. Fatty diabetic lung: altered alveolar structure and surfactant protein expression. Am J Physiol Lung Cell Mol Physiol. 2010;298(3):L392-403.

51. Elliot JG, Donovan GM, Wang KCW, Green FHY, James AL, Noble PB. Fatty airways: implications for obstructive disease. Eur Respir J. 2019;54(6).

52. Patel VB, Basu R, Oudit GY. ACE2/Ang 1-7 axis: A critical regulator of epicardial adipose tissue inflammation and cardiac dysfunction in obesity. Adipocyte. 2016;5(3):
306-11.

53. Watanabe M, Risi R, Tuccinardi D, Baquero CJ, Manfrini S, Gnessi L. Obesity and SARS-CoV-2: a population to safeguard. Diabetes/Metabolism Research and Reviews. 2020;3325..

54. Singh S, Loke YK. Drug safety assessment in clinical trials: methodological challenges and opportunities. Trials. 2012;20(13):138.

55. Morrison AR, Johnson JM, Ramesh M, Bradley $P$, Jennings J, Smith ZR. Letter to the Editor: Acute hypertriglyceridemia in patients with COVID-19 receiving tocilizumab. J of Med Virol. 2020; doi: 10.1002/jmv.25907.

56. Glund $S$, Krook A. Role of interleukin-6 signaling in glucose and lipid metabolism. Acta Physiol (Oxf). 2008;192(1):37-48.

57. Devaud JC, Berger MM, Pannatier A, et al. Hypertriglyceridemia: a potential side effect of propofol sedation in critical illness. Intens Care Med. 2012;38(12):1990-1998.

58. Luo P, Liu Y, Qiu L, Liu X, Liu D, Li J. Tocilizumab treatment in COVID-19: a single center experience. $J$ of Med Virol. 2020:1-5

59. McCreary EK, Pouge JM. COVID-19 Treatment: A Review of Early and Emerging Options. Op For Infect Dis. 2020;7(4):105.

60. Maclntyre CR, Chughtai AA. Facemasks for the prevention of infection in healthcare and community settings. BMJ, 2015;350:h694.

61. Xiao J, Shiu EY, Gao H, Wong JY, Fong MW, Ryu $\mathrm{S}$, Cowling BJ. Nonpharmaceutical measures for pandemic influenza in nonhealthcare settings-personal protective and environmental measures. Emerg Infect Dis. 2020;26(5):967-975.

62. Leung, Nancy HL, Daniel KW Chu, Eunice YC Shiu, KwokHung Chan, James J. McDevitt, Benien JP Hau, Hui-Ling Yen HL, Li Y, Ip DK, Peiris JM, Seto WH. Respiratory virus shedding in exhaled breath and efficacy of face masks. Nat Med, 2020:1-5.

63. Hsu JJ, Gaynor P, Kamath M, Fan A, Al-Saffar F, Cruz D, Nsair A. COVID-19 in a High-Risk Dual Heart and Kidney Transplant Recipient. Am J of Transplan. 2020. doi: 10.1111/AJT.15936

64. Larue B. Labour issues and COVID-19. Can J of Agri Econo, 2020. doi:10.1002/cjag.12233.

65. GuanWJ, Ni ZY, Hu Y, Liang WH, Ou CQ, He JX, Liu L, Shan $\mathrm{H}$, Lei CL, Hui DS, Du B. Clinical characteristics of 2019 novel coronavirus infection in China. medRxiv. 2020.

66. Corman VM, Landt O, Kaiser M, Molenkamp R, Meijer A, Chu DK, Bleicker T, Brunink S, Schneider J, Schmidt ML, Mulders DG. Detection of 2019 novel coronavirus (2019-nCoV) by real-time RT-PCR. Eurosurveillance, 2020;25(3):2000045.

67. Chan JF, Yuan S, Kok KH, Chan JFW, Yuan S, Kok KH, To KKW, Chu $H$, Yang J, Xing F, Liu J, Yip CCY, Poon RWS, Tsoi HW. A familial cluster of pneumonia associated with the 2019 novel coronavirus indicating person-toperson transmission: a study of a family cluster. The Lancet. 2020;395(10223):514-523.

68. Bai, Y, Lingsheng Y, Tao W, et al. Presumed asymptomatic carrier transmission of COVID-19. JAMA. 2020. 
69. Hedou M, Carsuzaa F, Chary E, Hainaut E, CazenaveRoblot F, Masson Regnault M. Comment on "Cutaneous manifestations in COVID-19: a first perspective" by Recalcati S. J the Europ Acad of Dermatol and Venereol. 2020.

70. Wang $M$, Cao $R$, Zhang $L$, et al. Remdesivir and chloroquine effectively inhibit the recently emerged novel coronavirus (2019-nCoV) in vitro. Cell Res. 2020;30:269-271.

71. Lan J, Ge J, Yu J, et al. Structure of the SARS-CoV-2 spike receptor-binding domain bound to the ACE2 receptor. Nature. 2020;1-9.

72. Gui, M. et al. Cryo-electron microscopy structures of the SARS-CoV spike glycoprotein reveal a prerequisite conformational state for receptor binding. Cell Res. 27, 119-129 (2017). https://doi.org/10.1038/cr.2016.152.

73. Song W, Gui M, Wang X, Xiang Y. Cryo-EM structure of the SARS coronavirus spike glycoprotein in complex with its host cell receptor ACE2. PLoS Pathog. 2018;14:1007236

74. Kirchdoerfer RN, Wang N, Pallesen J, et al. Stabilized coronavirus spikes are resistant to conformational changes induced by receptor recognition or proteolysis. Sci Rep. 2018;8(1):1-11.

75. Yuan Y, Yuan Y, Cao D, et al. Cryo-EM structures of MERS-CoV and SARS-CoV spike glycoproteins reveal the dynamic receptor binding domains. Nat Commun. 2017;8:15092.

76. Walls A C, Park YJ, Tortorici MA, Wall A, McGuire AT, Veesler D. Structure, Function, and Antigenicity of the SARS-CoV-2 Spike Glycoprotein. Cell. 181(2):281-292.

77. Letko M, Marzi A, Munster V. Functional assessment of cell entry and receptor usage for SARS-CoV-2 and other lineage B betacoronaviruses. Nat Microbiol. 2020;5:562-569.

78. Hoffmann M, Kleine-Weber H, Schroeder S, et al. SARSCoV-2 Cell Entry Depends on ACE2 and TMPRSS2 and Is Blocked by a Clinically Proven Protease Inhibitor. Cell. 2020;181(2):271-280.

79. Tian X, Li C, Huang A, et al. Potent binding of 2019 novel coronavirus spike protein by a SARS coronavirusspecific human monoclonal antibody. Emerging Microbes \& Infections. 2020;9(1):382-385.

80. Wrapp D, Wang N, Corbett KS, et al. Cryo-EM structure of the 2019-nCoV spike in the prefusion conformation. Science. 2020;367:1260-1263.

81. Wan Y, Shang J, Graham R, Baric RS, Li F. Receptor recognition by novel coronavirus from Wuhan: An analysis based on decade-long structural studies of SARS. J Virol. 2020;94:00127-20.

82. Wu F, Zhao S, Yu B, et al. A new coronavirus associated with human respiratory disease in China. Nature. 2020;579:265-269.

83. Zhu N, Zhang D, Wang W, et al. A Novel Coronavirus from Patients with Pneumonia in China. N Engl J Med. 2019;382:727-733.

84. Dong E, Du H, Gardner L. An interactive web-based dashboard to track COVID-19 in real time. Lancet Infect Dis. (epub 19 Feb 2020)

85. Wang Ke, Wei Zhao, Ji Li, Weiwei Shu, and Jun Duan. The experience of high-flow nasal cannula in hospitalized patients with 2019 novel coronavirus- infected pneumonia in two hospitals of Chongqing, China. Annals of Intensive Care. 2020;10:1-5.

86. Xu M, Lee EM, Wen Z, et al. Identification of smallmolecule inhibitors of Zika virus infection and induced neural cell death via a drug repurposing screen. Nature Medicine. 2016;22:1101-1107.

87. Aulner N, Danckaert A, Ihm J, Shum D, Shorte SL. Next-Generation Phenotypic Screening in Early Drug Discovery for Infectious Diseases. Trends in Parasitology. 2019.

88. Anand K, Palm GJ, Mesters JR, Siddell SG, Ziebuhr J, Hilgenfeld R. Structure of coronavirus main proteinase reveals combination of a chymotrypsin fold with an extra $\alpha$-helical domain. The EMBO Journal. 2002;21:3213-3224.

89. Yang HT, Yang $\mathrm{H}$, Yang $\mathrm{M}$, et al. The crystal structures of severe acute respiratory syndrome virus main protease and its complex with an inhibitor. Proceedings of the National Academy of Sciences. 2003;100(23):1319013195.

90. Pillaiyar T, Manickam M, Namasivayam V, Hayashi Y, Jung SH. An Overview of Severe Acute Respiratory Syndrome-Coronavirus (SARS-CoV) 3CL Protease Inhibitors: Peptidomimetics and Small Molecule Chemotherapy. J of Med Chem. 2016;59:6595-6628.

91. Hegyi A, Ziebuhr J. Conservation of substrate specificities among coronavirus main proteases. $J$ of Gen Virol. 2002;83:595-599.

92. Singh N, Halliday AC, Thomas JM, et al. A safe lithium mimetic for bipolar disorder. Nature Communications. 2013;4:1-7.

93. Lynch E, Kil J. Development of ebselen, a glutathione peroxidase mimic, for the prevention and treatment of noise-induced hearing loss. Seminars in Hearing. 2009;30:047-055.

94. Kil J, Lobarinas E, Spankovich C, Griffiths SK, Antonelli PJ, Lynch ED, Le Prell CG. Safety and efficacy of ebselen for the prevention of noise-induced hearing loss: a randomised, double-blind, placebo-controlled, phase 2 trial. The Lancet. 2017;390(10098):969-979.

95. Renson M, Etschenberg E, Winkelmann J. 2-Phenyl-1, 2-benzisoselenazol-3 (2H)-one containing pharmaceutical preparations and process for the treatment of rheumatic diseases. U.S. Patent . 1982;4:352,799.

96. Masaki C, Sharpley AL, Cooper CM, et al. Effects of the potential lithium-mimetic, ebselen, on impulsivity and emotional processing. Psychopharmacology. 2016;233:2655-2661.

97. Hamming I, Timens W, Bulthuis ML, Lely AT, Navis $\mathrm{G}$, van Goor H. Tissue distribution of ACE2 protein, the functional receptor for SARS coronavirus. A first step in understanding SARS pathogenesis. J Pathol. 2004;203(2):631-637.

98. Vickers C, Hales P, Kaushik V, et al. Hydrolysis of biological peptides by human angiotensin-converting enzyme-related carboxypeptidase. J Biol Chem. 2002;277 (17):14838-43.

99. Kow CS, Syed Tabish RZ, Syed SH. Cardiovascular Disease and Use of Renin-Angiotensin System Inhibitors in COVID-19. Am Jour of Cardio Drug. 
2020;1-5.

100. Gao Y, Yan L, Huang Y, et al. Structure of the RNAdependent RNA polymerase from COVID-19 virus. Sci. 2020.

101. Savarino A, Di Trani L, Donatelli I, Cauda R, Cassone A. New insights into the antiviral effects of chloroquine. Lancet Infect Dis. 2006;6:67-69.

102. Vincent MJ, Bergeron E, Benjannet S, et al. Chloroquine is a potent inhibitor of SARS coronavirus infection and spread. Virol J. 2005;2(1): 69.

103. Mackenzie AH. Antimalarial drugs for rheumatoid arthritis. Am J Med. 1983;75(6):40-45.

104. Gautret P, Lagier J Christophe, Parola P, et al. Hydroxychloroquine and azithromycin as a treatment of COVID-19: results of an open-label non-randomized clinical trial, Int J of Antimicro Agents. 2020;105949

105. Ceribelli A, Francesca M, Maria De S, et al. Recommendations for coronavirus infection in rheumatic diseases treated with biologic therapy. J Autoimmun. 2020;102442.

106. van den Brink EN, Ter Meulen J, Cox F, et al. Molecular and biological characterization of human monoclonal antibodies binding to the spike and nucleocapsid proteins of severe acute respiratory syndrome coronavirus. J Virol. 2005;79:1635-1644.

107. Prabakaran $\mathrm{P}$, Gan J, Feng $\mathrm{Y}$, et al. Structure of severe acute respiratory syndrome coronavirus Receptor binding domain complexed with neutralizing antibody. J Biol Chem. 2006;281:15829-15836.

108. Hwang WC, Lin Y, Santelli E, et al. Structural basis of neutralization by a human anti-severe acute respiratory syndrome spike protein antibody, 80R. J Biol Chem. 2006;281:34610-34616.

109. Alhazzani W, Moller MH, Arabi YM, et al. Surviving Sepsis Campaign: guidelines on the management of critically ill adults with Coronavirus Disease 2019 (COVID-19). Intensive Care Medicine. 2020;1-34.

110. Sarris J, Logan AC, Akbaraly TN. International Society for Nutritional Psychiatry Research. Nutritional medicine as mainstream in psychiatry. Lancet Psychiatry. 2015;2(3):271-4.

111. Lippi G, Henry B M, Sanchis-Gomar F. Physical inactivity and cardiovascular disease at the time of coronavirus disease 2019 (COVID-19). Eur J of Prev Cardiol. 2020. 